\title{
Positive and Negative Perceptions of Bumiputra And Non-Bumiputra Students on Professional Qualification
}

\author{
Noor Asidah Abd. Rashid ${ }^{1, *}$, and A.H. Fatima ${ }^{2}$ \\ ${ }^{1}$ Sekolah Menengah Kebangsaan Jengka Pusat \\ ${ }^{2}$ International Islamic University Malaysia
}

\begin{abstract}
Bumiputra and non-Bumiputra students may come from various economic backgrounds and culture. This may influence their perception on their career choice of pursuing a professional accounting qualification. Thus, this study investigates the difference in positive and negative perceptions of Bumiputra and non-Bumiputra students on pursuing a professional qualification upon graduation. A questionnaire survey method was used to collect the data from final year accounting students from five public and three private universities in Malaysia. Means and independent sample t-tests results were analysed. Results indicated that there are only a few significant differences between Bumiputra and nonBumiputra students on positive and negative perceptions on becoming professional accountants. As perception frames action, these findings would be useful to the Malaysian Institute of Accountants as well as professional bodies to attract both Bumiputra and non-Bumiputra graduates to become professional accountants.
\end{abstract}

\section{Introduction}

Globalisation, advances in information technology, the multidisciplinary economic environment and new business relationships have changed the accounting profession. Due to these changes, the accounting profession requires a new breed of professional accountants with multi-skills, competence and integrity. In Malaysia, the title "professional accountant" is awarded to a member of the Malaysian Institute of Accountants' (MIA), having acquired education from a recognized programme and having attained the required training [1].

The need for professional accountants has been recognized and declared by the International Federation of Accountants [2]. This need is echoed by Malaysia; Malaysia has announced that it would require about 60,000 accountants by the year 2020 [3]. In Malaysia, graduates from accredited bachelor of accounting programmes are the primary source, contributing to 59 per cent of newly registered accountants in 2013 [4]. However, this approximates to only 18 percent of accounting graduates each year. Thus, there is a dire need in Malaysia to attract accounting graduates to get professionally qualified.

*Corresponding author: puan_noora@yahoo.com 
However, 'one-size-fits-all' approach to attracting graduates may not be conducive in the Malaysian environment as Malaysia is a multi-racial country.

Since the intention to pursue a professional qualification would be framed by positive and negative perceptions towards it, this study aims to investigate these perceptions from both Bumiputra and non-Bumiputra students. This is because based on Malaysia's census in 2010, about 60 percent of the population are Bumiputras (Malays and aboriginal tribes), thus the remaining 40 percent are non-Bumiputras (Chinese, Indians and others). This study also compares the difference in perceptions between the Bumiputra and non-Bumiputra groups on pursuing a professional qualification. The findings of this study would be useful to professional bodies to attract graduates from both Bumiputra and non-Bumiputra groups by promoting graduates' positive perceptions and appeasing their negative perceptions on professional qualifications. The MIA would also benefit by having more members.

Subsequent to the introduction, the next section briefly reviews the relevant literature to identify the gap. Then, theory, hypotheses and research method are discussed prior to the discussion of results and findings. The study concludes by contemplating the implications, limitations and suggestions for future research.

\section{Literature Review}

Students' perception can be expressed as students' attitude [5] or beliefs [6]. This study accepts the latter definition. Understanding students' perceptions of accountancy profession is an important step in identifying the students' intention in pursuing the professional qualification as students' career choice is highly influenced by students' belief that was formed through perception [7, 8]. Literature on perception in relation to accounting may be classified into perception on accounting as a profession $[9,10]$, which would affect perception of students in taking accounting as a major $[11,12]$ as well as perception of students to become professionally qualified. The review of the literature will focus on relevant studies related to perception of students on becoming professional accountants, particularly in the Malaysian context.

In Malaysia, a prior study found that job security and stability, opportunities for advancement and students' perception towards the profession were the main variables that influenced students' decision to sit for professional examinations [13]. Nevertheless, the learning environment plays a role of moderating the attitude of students, and it significantly moderates the attitude-intention relationship [14]. However, non-commitment by accounting students could still exist although undergraduate accounting programmes are designed to prepare students for a career in the accounting profession [15]. Hence, in addition to the learning environment, environmental factor (such as expected income), people related factor (such as the accountants work that apply what they have learnt during college) and behaviour capability (such as type of academic institution and self-motivation) have significant effects on accounting undergraduates' preference to practice as Chartered Accountants [16].

Literature also shows that there are limited studies that compare various ethnicities or racial groups in Malaysia, although there are several in other countries $[17,18,19]$. Nevertheless, there are studies that compare the differences between the perception of Malay and Chinese accounting students [20], Malaysian students and international students [21], and Malaysian Chinese accounting students and English students [22]. In general, the findings revealed that there were differences in perception by students of different racial and ethnic background.

The literature review clearly indicates that there is a gap in the study on the perceptions of Bumiputra and non-Bumiputra students. This study is warranted as the above literature shows that there are differences in perception between different ethnic or cultural groups. 


\section{Theory, Hypothesis and Research Method}

The Theory of Reasoned Action (TRA) model emphasizes on the specific process by which an individual makes choices, and is applied in understanding students' career decisions [23]. The TRA model was developed in order to establish links between attitudes, intentions, norms, beliefs and behaviours of individuals [24]. Generally, attitudes and social norms form beliefs, which would lead to intention and later may result in performance of behaviour. However, in this study, only the initial stage of the TRA model is focused on, i.e. perceptions (positive and negative). This is because positive perception is likely to influence positive intention to pursue a professional accounting qualification, whereas negative perception is likely to deter the student from pursuing the qualification.

Although the theory cannot be used to specifically explain a difference in perception between Bumiputra and non-Bumiputra students, there is however evidence from prior literature $[17,20]$, which supports a difference between perceptions of different racial or ethnic groups. Thus, based on the above, the following hypothesis is framed:

$\mathrm{H}_{1}$ : There is a significant difference between perception of Bumiputra and nonBumiputra students on pursuing professional qualification.

The study used a survey instrument adapted from prior literature [25, 26, 27] to gather the positive and negative perception of students on pursuing a professional qualification. The responses were measured using a five-point likert scale from 1 (strongly disagree) to 5 (strongly agree).

Prior to distributing the questionnaires, a pilot test was performed to enhance the validity and understandability of the questionnaire. Then, a total of 500 questionnaires were distributed to 5 public and 3 private universities in Malaysia. 352 usable responses $(70.4 \%)$ were received. Of these, 66.5 percent were from Bumiputra and 32 percent from nonBumiputra, which approximates the population of Malaysia.

Test of reliability was performed using Cronbach's alpha. Then, in order to test $\mathrm{H}_{1}$, means were used to calculate the responses and independent sample t-tests were used to measure the differences.

\section{Results and Discussion of Findings}

Out of the questionnaires returned, 344 were useable, resulting in 68.8 percent of the initially distributed questionnaires. The Cronbach's alpha for positive and negative perceptions were 0.749 and 0.935 , respectively. Therefore, the questionnaire items are considered acceptable in terms of reliability as Cronbach's alpha in excess of 0.7 is acceptable [28]. From the 344 useable questionnaires, 67 percent and 23 percent of the respondents were Bumiputra and non-Bumiputra, respectively. The majority of the respondents were female students ( 75 percent). As for Cumulative Grade Point Average (CGPA), 25 percent, 49 percent and 26 percent of the respondents had a CGPA of 3.5 and above, between 3 and 3.49 , and below 3 , respectively.

Table 1 provides the results on the differences in perception between Bumiputra and non-Bumiputra students. Based on the p-value of the Independent sample t-test, the results generally indicate that the perception of Bumiputra and non-Bumiputra are not significantly different. However, there are some exceptions on "gives you authority/power", "positively contribute to society" and "allows for independent autonomy". In all three cases, the average perception of the Bumiputra students was significantly higher, but only to a weak extent (significant at 10 percent significance level) than their non-Bumiputra counterpart. The results of the Independent sample t-test were confirmed by the Mann-Whitney test.

In analyzing the means, 'good salary', 'greater choice for employability' and 'prospects for promotion' are the top three benefits of becoming professionally qualified as perceived 
by the latter group. Contrarily, 'allows independence', and 'having job security' is perceived to be the top benefits by the Bumiputra students. A 'good salary', 'gives authority, 'interesting and exciting profession' and 'enhances creativity' ties for the third positive perception for the Bumiputra group. The findings as presented in Table 1 suggest that there are indeed some differences in the perception of Bumiputra and non-Bumiputra students, but they are minimal. However, the differences in perception seem to increase on the potential negative aspects of pursuing a professional qualification.

Table 1. The difference in positive perception between Bumiputra and non-Bumiputra students on becoming a professional accountant.

\begin{tabular}{|l|c|c|c|}
\hline \multicolumn{1}{|c|}{ STATEMENTS } & Bumiputra & $\begin{array}{c}\text { non- } \\
\text { Bumiputra }\end{array}$ & p-value \\
\hline Gives a good salary & 4.039 & 4.093 & 0.507 \\
\hline Prestigious lifestyle and social status & 3.885 & 4.009 & 0.168 \\
\hline Future high earnings potential & 4.000 & 3.932 & 0.386 \\
\hline Promotion prospects or opportunities & 4.017 & 4.042 & 0.765 \\
\hline To have greater employability choices & 3.944 & 4.051 & 0.220 \\
\hline Potential for personal growth and development & 3.992 & 3.873 & 0.154 \\
\hline Gives you authority / power & 4.039 & 3.881 & 0.058 \\
\hline Positively contribute to society & 4.021 & 3.873 & 0.071 \\
\hline Opportunity to work for a large corporation & 3.996 & 3.864 & 0.118 \\
\hline $\begin{array}{l}\text { Challenging, interesting, satisfying and } \\
\text { exciting profession }\end{array}$ & 4.039 & 3.983 & 0.504 \\
\hline Opportunity to choose career specialization & 3.996 & 3.873 & 0.141 \\
\hline Opportunity to apply skills and abilities & 4.000 & 3.873 & 0.126 \\
\hline Allows you to enjoy a quality family life & 4.004 & 3.958 & 0.571 \\
\hline Assure good physical working conditions & 4.009 & 3.975 & 0.686 \\
\hline Enhance your creativity & 4.039 & 4.009 & 0.724 \\
\hline Has job security & 4.043 & 3.958 & 0.307 \\
\hline Allows for independence & 4.060 & 3.898 & 0.057 \\
\hline Gives you a chance to interact with various people & 4.004 & 3.983 & 0.801 \\
\hline
\end{tabular}

The results in Table 2 indicate that there is significant difference (significant at 5 percent significance level) in perception on 'there are too many hurdles to qualify', 'there is no time to relax in the first few years' and 'it costs a lot of money to become a Professional Accountant'. The means on 'skills and maths background is required to be a Chartered Accountant' are only weakly significantly different (significant at 10\% significant level).

Overall, the non-Bumiputra students seem to perceive these negative aspects of pursuing a professional qualification more negatively, based on the means. Furthermore, 'limited free time' and professional accounting qualifications being expensive seem to be the primary concern for Bumiputra and non-Bumiputra students, respectively. Meanwhile, 'recent negative image of the profession', and 'A Chartered Accountant is not as exciting as other careers' are the other main concerns of the Bumiputra students. On the other hand, for the non-Bumiputra students, their other main concerns are 'there are too many hurdles to qualify', 'low earnings in the initial employment years', 'personal liabilities for malpractice', 'market for a professional accountant is saturated', 'there is no time to relax in the first few years' and 'skills and math background is required to be a Chartered Accountant'. Based on the overall findings of perceived benefits and negative aspects on becoming a professional accountant, Hypothesis 1 is partially supported as there are only some significant differences between the perception of Bumiputra and non-Bumiputra students. In referring to TRA, these perceived benefits (positive perception) are likely to influence an intention to pursue a professional qualification, whereas negative perceptions are likely to deter it. However, as this paper's objective is to gather these positive and 
negative perceptions, thus a future study should explore whether these perceptions do indeed have an effect on intention of students to pursue a professional qualification.

Table 2. The difference in negative perceptions between Bumiputra and non-Bumiputra students on becoming a professional accountant.

\begin{tabular}{|l|c|c|c|}
\hline \multicolumn{1}{|c|}{ STATEMENT } & Bumiputra & $\begin{array}{c}\text { non- } \\
\text { Bumiputra }\end{array}$ & p-value \\
\hline $\begin{array}{l}\text { It costs a lot of money to become a Professional } \\
\text { Accountant }\end{array}$ & 3.85 & 4.364 & 0.037 \\
\hline $\begin{array}{l}\text { It takes too much time to qualify as a Professional } \\
\text { Accountant }\end{array}$ & 3.80 & 4.227 & 0.100 \\
\hline There are too many hurdles to qualify & 3.75 & 4.318 & 0.029 \\
\hline Limited free time & 4.15 & 4.046 & 0.685 \\
\hline Low earnings in the initial employment years & 3.90 & 4.318 & 0.092 \\
\hline Recent negative image of the profession & 4.05 & 4.227 & 0.487 \\
\hline Personal liabilities for malpractice & 3.90 & 4.318 & 0.092 \\
\hline Market for a professional accountant is saturated & 3.90 & 4.318 & 0.092 \\
\hline $\begin{array}{l}\text { Chartered Accountant firms demand long and } \\
\text { inflexible hours }\end{array}$ & 3.90 & 4.273 & 0.144 \\
\hline $\begin{array}{l}\text { A Chartered Accountant is not as exciting as other } \\
\text { careers }\end{array}$ & 4.00 & 4.227 & 0.366 \\
\hline There is no time to relax in the first few years & 3.80 & 4.318 & 0.036 \\
\hline $\begin{array}{l}\text { Skills and math background is required to be a } \\
\text { Chartered Accountant }\end{array}$ & 3.85 & 4.318 & 0.054 \\
\hline
\end{tabular}

\section{Conclusion}

The findings of the study have certain implications. Firstly, the positive perception of Bumiputra and non-Bumiputra students on pursuing an accounting qualification is minimal. Thus, professional accounting bodies can use similar marketing strategies to attract both Bumiputra and non-Bumiputra students. However, the professional accounting bodies as well as MIA have to realise that the negative perceptions perceived by these students are equally important. Hence, accounting bodies should also attempt to address these concerns by the students. Moreover, more of the negative perceptions are significantly different between Bumiputra and non-Bumiputra students. Therefore, these concerns have to be addressed based on ethnic groups and cultural background, instead of assuming that all students have the same concerns.

The study's limitations can be overcome by future studies by extending the investigation to students from all universities in Malaysia. Also, a larger sample size would enable future studies to attain the perception of the main racial groups in Malaysia, instead of just grouping them into Bumiputra and non-Bumiputra. Moreover, since this study only investigates the initial stage of TRA, which is perception, future studies could extend this study by determining whether positive perception does indeed lead to the intended performance, i.e. pursuing professional qualification. Nevertheless, the study has produced findings that would be useful to accounting professional bodies. 


\section{References}

1. Malaysian Institute of Accountants. By-Laws (On Professional Ethics, Conduct and Practice) www.mia.org.my/ (2010)

2. IFAC. Definition of Professional Accountant. https://www.ifac.org/system/files/ meetings/ files/Definition Professional Accountant Presentation.pptx (2011)

3. M. Abdullah. Utusan Malaysia. http://www.utusan.com.my/utusan (2001)

4. Malaysian Institute of Accountants. Annual report 2013. (2013)

5. T. McDowall, B. Jackling. Asian Rev. Accounting, 18, 30 (2010)

6. B.P. Green, P. Graybeal. J. Education for Business, 86, 100 (2011)

7. A. Ferreira, A. Santoso. Accounting \& Finance 48, 209 (2008)

8. H. Dalci, M. Arasli, S. Tümer, J. Baradarani. Acc. Emerging Economies, 3, 145 (2013)

9. W.S. Albrecht, R.J. Sack. Accounting Education 16, 5 (2000)

10. J. Mbawuni. Int. Education Studies 8, 9 (2015)

11. P. Marriott, N. Marriott, N. Accounting Education: Int. J. 12, 113 (2003)

12. B. Jackling, P.D. Lange, J. Philips, Sewell. Accounting Research J. 25, 113 (2012)

13. M. Mustapha, M.H.A. Hassan. Int. J. Education 4, 1 (2012)

14. S.Y. Foong, C.H. Khoo. J. Acc. Emerging Economies 5, 202 (2015)

15. Z. Ahmad, H. Ismail, R.N. Anantharaman. Education \& Training 57, 360 (2015)

16. N. Jaffar, N. Ismail, S.M. Zahid. Accountancy Bus. \& the Public Interest 43 (2015)

17. P. Auyeung, J. Sands, J. Accounting Education: Int. J. 6, 13 (1997)

18. J.E. Myburgh. Meditari Accountancy Research 13, 35 (2005)

19. P.L. Wessels, L.P. Steenkamp. Meditari Accountancy Research 17, 117 (2009)

20. E.K. Ghani, J. Said. Canadian Social Science 5 (2009).

21. S. Abidin, N.A. Zaluki, N. Salmi. Malaysian Accountancy 1, 4 (2011)

22. E. Germanou, T. Hassall, Y. Tournas. Asian Rev Accounting 17, 136 (2009)

23. M. Strader, B. Katz. J Social Psy 130, 141 (1990)

24. M. Fishbein, I. Ajzen. Belief, attitude, intention \& behavior: Introduction to theory \& research $(1975)$

25. J. Paolillo, R. Estes. Accounting Review 57, 785 (1982)

26. K. Ahmed, K. Alam, M. Alam. Accounting Education 6, 325 (1997)

27. S.M. Jackman, A. Hollingworth. http://files.iaaer.org/publications/COSMOSvol15 no2.pdf? 1403722838 (2004)

28. U. Sekaran, R. Bougie. Research methods for business: A skill building approach $\left(5^{\text {th }}\right.$ ed.) (2010) 